\title{
PENDUGAAN LAJU SEDIMENTASI DENGAN MENGGUNAKAN MODEL USLE DI SUB DAS BIYONGA Sedimentation Rate Estimation Using USLE Models In Biyonga Watershed
}

\author{
Sartika Moha ${ }^{1}$, Ivan Taslim², Risman Jaya ${ }^{2}$ \\ ${ }^{1}$ Sarjana Program Studi Geografi Universitas Muhammadiyah Gorontalo,Indonesia \\ ${ }^{2}$ Program Studi Geografi Universitas Muhammadiyah Gorontalo, Indonesia \\ Email Korespondensi: sartikamoha@ymail.com
}

DOI: http://dx.doi.org/10.31314/jsig.v3i1.559

Abstract - This research is conducted in Sub-watershed Biyonga area. The purpose of this research is to estimate the amount of sedimentation rate in Biyonga Sub-waters in the last five years from 2012 to 2016. A USLE model is used in this study to estimate the amount of sedimentation entering limboto lake. The results showed that for five years the Biyonga sub-watershed contributed Erosion of 5.870.145,93 ton/ha/year as well as the largest sedimentation of 1.402.507,01 ton/ha/syear. This means that the results of Biyonga Sub-watershed needed more serious handling.

Keywords: erosion, sedimentation, USLE, biyonga watershed

\begin{abstract}
Abstrak - Penelitian ini dilakukan di daerah Sub DAS Biyonga. Tujuan dari penelitian ini adalah untuk menduga besarnya laju sedimentasi pada Sub DAS Biyonga dalam lima tahun terakhir dari tahun 2012 hingga 2016. Sebuah model USLE digunakan dalam penelitian ini untuk menduga besarnya sedimentasi yang masuk ke Danau Limboto. Hasil penelitian menunjukan bahwa selama lima tahun Sub DAS Biyonga menyumbang Erosi sebesar 5.870.145,93 ton/ha/thn serta menymbang Sedimentasi terbesar yaitu sebanyak 1.402.507,01 ton/ha/thn. Artinya dari hasil tersebut Sub DAS Biyonga memerlukan penanganan yang lebih serius lagi.
\end{abstract}

Kata kunci: erosi, sedimentasi, USLE, daerah aliran sungai, biyonga 


\section{PENDAHULUAN}

Daerah Aliran Sungai (DAS) merupakan wilayah kesatuan ekosistem yang dibatasi oleh pemisah topografis dan berfungsi sebagai pengumpul, penyimpan dan penyalur air, sedimen, unsur hara melalui sistem sungai mengeluarkannya melalui outlet tunggal. Ketika hujan turun di daerah tersebut, maka air hujan tersebut akan mengalir ke sungai-sungai yang berada disekitarnya. DAS adalah suatu wilayah daratan yang secara topografi dibatasi oleh punggungpunggung bukit yang berfungsi menerima, menampung, menyimpan dan mengalirkan air hujan untuk kemudian menyalurkannya ke waduk, danau dan laut sebagai muara akhir melalui sungai utama (Asdak 2014).

Provinsi Gorontalo memiliki 10 Daerah Aliran Sungai (DAS) yaitu diantaranya adalah DAS Randangan, DAS Popayato, DAS Sumalata, DAS Paguyaman, DAS Tilamuta, DAS Bone, DAS Bolango, DAS Batudaa Bone Pantai, DAS Posso Atingola, DAS Limboto.Salah satu DAS yang masuk dalam kategori prioritas-kritis yaitu DAS Limboto yang merupakan bagian dari Satuan Wilayah Pengelolaan Daerah Aliran Sungai (SWP-DAS) Bone Bolango dengan luas sekitar 91.004 Ha. Kondisi kritis tersebut disebabkan oleh rusaknya lahan di Daerah Tangkapan Air (DTA) akibat karena perubahan lahan yang tidak terkendali di bagian hulu, sehingga mengakibatkan terjadi perubahan siklus hidrologi pada DTA tersebut. Kerusakan lahan diantaranya adalah berkurangnya tutupan vegetasi di daerah hulu DTA yang mengakibatkan hujan yang turun tidak dapat ditahan dan diserap oleh tanah, sehingga mengakibatkan aliran air permukaan (BPDAS Bone-Bolango,2013).

DAS Limboto merupakan DAS yang cukup luas yang memiliki 12 Sub DAS yang diantaranya yaitu Sub DAS Molamahu, Sub DAS Alo, Sub DAS Marisa, Sub DAS Pone, Sub DAS Pulubala, Sub DAS talumelito, Sub DAS Tuladenggi, Sub DAS Batu Layar, Sub DAS Pilolalenga, Sub DAS Tabongo, Sub DAS Payunga dan Sub DAS Biyonga bulota yang bermuara ke danau limboto. Dari 12 Sub DAS yang ada di DAS Limboto, salah satunya merupakan Sub DAS yang menjadi daerah penelitian, karena menurut penelitian Rawiyah Husnan tentang Intensitas Bed Load pada tahun 2007 bahwa salah satu Sub DAS yang ada di DAS Limboto yang menyumbang erosi dan sedimentasi paling besar adalah Sub DAS biyonga. Sehingga Sub DAS Biyonga merupakan salah satu dari Sub DAS yang ada di DAS Limboto dan memiliki prioritas tinggi dan memerlukan penanganan intensif untuk perencanaan pengendalian sedimentasi yang baik dan tepat saran.

Besarnya sedimentasi sangat penting untuk diketahui, guna untuk mengetahui kondisi kesehatan suatu DAS sehingga dengan demikian akan dapat diketahui pola dan upaya dari pengelolaan yang harus dilakukan. Untuk itu, karena belum adanya yang menelitipendugaan laju sedimntasi maka saya ingin meneliti pendugaan laju sedimentasi dengan menggunakan model The Universal Soil Loss Equation (USLE) dari data-data yang ada, sehingga penelitian ini bisa berguna untuk mencatat laju sedimentasi yang ada di Sub DAS Biyonga.

\section{METODE DAN DATA}

Penelitian ini dilaksanakan di Sub DAS Biyonga yang berada di dalam kawasan DAS Limboto di Kelurahan Biyonga, Kecamatan Limboto, Kabupaten Gorontalo yang terletak pada $\left(122^{0} 58^{\prime} 09^{\prime}-123^{0} 02^{\prime} 19^{\prime} \mathrm{BT}\right)-\left(0^{0} 36^{\prime} 06^{\prime}\right.$ ' - 0 046'55'’LU).

Alat yang digunakan dalam penelitian ini berupa:

a. Alat tulis menulis untuk mencatat hasil observasi lapangan

b. Global Possitioning System (GPS) digunakan untuk mengambil beberapa titik dilapangan untuk dikomplikasikan dengan data yang sudah ada seperti data penggunaan lahan, jenis tanah, dan kemiringan lereng.

c. Kamera digunakan untuk dokumentasi

d. Laptop Toshiba untuk pengolahan data erosi dan sedimentasi

e. Perangkat lunak untuk pengolah Kata Word dan Exel 2007

Bahan yang digunakan dalam penelitian ini merupakan data sekunder, diantaranya :

a. Data Curah Hujan yang diperoleh dari Badan Meterologi Klimatologi dan Geofisika Bandar Udara Djalaludin Gorontalo

b. Data Jenis Tanah untuk wilayah Sub DAS Biyonga yang diperoleh dariDinas Pekerjaan Umum dan Penataan Ruang Kab. Gorontalo 
c. Data Kemiringan Lereng wilayah Sub DAS Biyonga yang diperoleh dari Balai Pengelolaan Daerah Aliran Sungai Bone-Bolango

d. Data Penggunaan Lahan Wilayah Sub DAS Biyonga yang diperoleh dari Balai Pemantapan Kawasan Hutan.

Tahap Persiapan

Pada tahap persiapan melakukan studi literatur yang berkaitan dengan penelitian yang akan dilakukan, yang bersumber dari buku, jurnal penelitian, dan informasi lainnya yang didapatkan dari penelusuran di internet.

Tahap Pengumpulan Data

Pada tahapan ini dilakukan mengumpulkan bahan penelitian dari data sekunder yaitu diantaranya adalah :

a. Data Curah Hujan

Data curah hujan selama 5 tahun mulai dari tahun 2012 hingga tahun 2016 mendapatkan nilai $\mathrm{R}$ (Erosivitas Hujan) dengan persamaan Lenvain $2.21 \mathrm{R}_{\mathrm{M}^{1.3}}$.

b. Data Jenis Tanah

Data tanah berupa data jenis tanah yang ada di wilayah SubDAS Biyonga. Untuk menentukan nilai $\mathrm{K}$ (erodibilitas tanah) menggunakan persamaan dari rumus Wischmeier $\mathrm{K}=\left\{2.71^{*} 10^{-4}(12-\right.$ $\left.\left.\mathrm{OM})^{1.14}+3.25(\mathrm{~S}-2)+2.5(\mathrm{P}-3) / 100\right\}\right)$

c. Data Kemiringan Lereng

Untuk menentukan Faktor LS bisa dengan menggunakan tabel nilai LS yang didasarkan pada keadaan panjang dan gradien kemiringan lereng di lapangan khususnya Sub DAS Biyonga

d. Data Penggunaan Lahan

Pada pengukuran erosi dengan pendekatan USLE peta ini berfungsi menentukan faktor tanaman (C) dan faktor konservasi tanah (P).Selain mengacu pada peta penutupan lahan, pada penelitian ini faktor $\mathrm{C}$ dan faktor $\mathrm{P}$ dapat ditentukan melalui pengamatan langsung di lokasi penelitian dan juga wawancara dengan masyarakat sekitar serta dengan menggunakan tabel pengelolaan tanaman dan konservasi tanah.

Tahap Pengolahan Data

Pengolahan data pada penelitian ini menggunakan model USLE (Universal Soil Loss Equation) untuk menduga laju sedimentasi pada lokasi penelitian Sub DAS Biyonga.

Adapun pengolahan data yang dilakukan yaitu dengan melihat faktor-faktor yang mempengaruhi besarnya erosi dengan menentukan nilai-nilai yang mempengaruhi besarnya erosi seperti dibawah ini:

a. Nilai Erosivitas Hujan (R) yang di dapatkan melalui perhitungan berdasarkan rumus Lenvain $\left(\mathrm{R}=2.21 \mathrm{R}_{\mathrm{M}}{ }^{1.3}\right.$ atau $\mathrm{R}=2.21$ x Curah hujan maksimal bulanan ${ }^{\wedge} 1.3$ ) Dimana $\mathrm{R}$ merupakan Erosivitas Hujan, $\mathrm{Rm}=$ Curah hujan maksimal bulanan).

b. Nilai Erodibilitas Tanah (K) didapatkan melalui Rumus Wischmeier $\left(\mathrm{K}=\left\{2.71 * 10^{-4}(12-\right.\right.$ $\left.\left.\mathrm{OM})^{1.14}+3.25(\mathrm{~S}-2)+2.5(\mathrm{P}-3) / 100\right\}\right)$ Dimana $\mathrm{OM}=$ Persen unsur organik, $\mathrm{S}=$ kode klasifikasi struktur tanah, $\mathrm{P}=$ Permeabilitas tanah, dan $\mathrm{M}=$ Persentase ukuran partikel (\% debu + pasir sangat halus) * (100 - \% liat). Adapun untuk menentukan Nilai dari K dapat dilihat dalam tabel seperti dibawah ini tetapi dengan memperhatikan beberapa unsur tanah diantaranya:

1. Bahan Organik Tanah $(\mathrm{OM})$

Berdasarkan penelitian yang pernah dilakukan oleh Ilahude dkk pada tahun 2012 bahwa

Unsur organik di lokasi tersebut dikategorikan sedang atau bernilai $7 \%$

2. Permeabilitas Tanah $(\mathrm{P})$

Penelitian Nurdin tahun 2012 mengatakan bahwa kelas permeabilitas tanah di Sub Das Biyonga dikategorikan agak cepat atau bernilai $11,5 \mathrm{~cm} / \mathrm{jam}^{-1}$

3. Tekstur Tanah (M)

Kelas tekstur tanah untuk Sub Das Biyonga berdasarkan penelitian Nurdin tahun 2012 di kategorikan lempung berdebu (\% Pasir $=36,15$ dan \% Debu 49,41) 
4. Struktur Tanah (S)

Sub Das Biyonga berdasarkan penelitian Nurdin pada tahun 2012 dikategorikan gumpal bersudut atau bernilai 4 .

5. Nilai Kemiringan Lereng dan Panjang Lereng (Ls) didapatkan berdasarkan tabel nilai kelas kelerengan.

6. Nilai $\mathrm{C}$ untuk berbagai jenis tanaman dan pengelolaan tanaman didapatkan dengan cara survey langsung dilapangan dengan menggunakan tabel Nilai Faktor Tanaman.

7. Nilai Faktor P pada berbagai aktivitas konservasi tanah didapatkan melalui tabel Nilai konservasi Tanah.

Selanjutnya nilai A (perkiraan besarnya erosi total) dapat dihitung sesui dengan Rumus USLE:

$$
\mathrm{A}=\mathrm{R} . \mathrm{K} \text {.LS .C .P }
$$

Dimana:

A: Perkiraan besarnya erosi total (ton/ha/thn)

R: Faktor Erosivitas Hujan

K: Faktor Erodibilitas Tanah

LS: Faktor panjang lereng dan kemiringan lereng

C: Faktor pengelolaan tanaman

P: Konservasi tanah

Kemudian Penetapan SDR (Sediment Delivery Ratio) dalam Arsyad yaitu : (SDR $=0.41 \mathrm{~A}$ $\left.{ }^{-0.3}\right) .\left(\mathrm{SDR}=\right.$ Rasio pelepasan Sedimen \%) dan $\left(\mathrm{A}=\right.$ Luas DAS $\left(\mathrm{km}^{2}\right)$. Dimana antara erosi dan sedimentasi memiliki hubungan pada luaran DAS yang dirumuskan dalam bentuk Nisbah Hantaran Sedimen (SDR).

Setelah hasil A dan SDR di dapat, selajutnya menghitung besarnya sedimen yang berasal dari erosi yang terjadi di Sub DAS Biyonga dengan menggunakan rumus sebagai berikut:

$$
\mathrm{Y}=\mathrm{E}(\mathrm{SDR}) \mathrm{A}
$$

Dimana :

Y: Hasil Sedimentasi persatuan luas (ton/ha/thn)

E: $\quad$ Erosi Total

SDR: Rasio pelepasan sedimen

\section{HASIL DAN PEMBAHASAN}

\section{Pendugaan Laju Erosi}

Pendugaan laju erosi di SUB DAS Biyonga yang menggunakan metode USLE, membutuhkan beberapa faktor diantaranya:

a. Erosivitas Hujan (R)

Berdasarkan data curah hujan Sub Das Biyonga yang diperoleh dari stasiun BMKG Djalaludin Kabupaten Gorontalo sejak tahun 2012 hingga tahun 2016 yang dihitung menggunakan persamaan lenvain. Berdasarkan hasil perhitungan yang menggunakan rumus lenvain di dapatkan bahwa pada tahun 2012 erosivitas hujan berjumlah 1305, pada tahun 2013 erosivitas hujan berjumlah $1147 \mathrm{~mm}, 2014$ berjumlah $839 \mathrm{~mm}$, tahun 2015 berjumlah $527 \mathrm{~mm}$ dan pada tahun 2016 berjumlah $1205 \mathrm{~mm}$.

b. Erodibilitas Tanah

Faktor Erodibilitas tanah di dapatkan dengan menggunakan persamaan Wischmeier diantaranya sebgai berikut:

$$
\begin{aligned}
\mathrm{K} \quad & =\{2,71 * 10-4(12-\mathrm{OM}) \mathrm{M} 1,14+3,25(\mathrm{~S}-2)+2,5(\mathrm{P}-3)\} / 100 \\
& =\{2,71 * 10-4(12-7) 85,561,14+3,25(4-2)+2,5(11,5-3)\} / 100 \\
& =\{2,71 * 10-4(5) * 159,51+3,25(2)+2,5(8,5)\} / 100 \\
& =27,9661 / 100 \\
& =0,279661 \mathrm{Ton} / \mathrm{kg}
\end{aligned}
$$


Berdasarkan perhitungan diatas dengan menggunakan persamaan Wischmeir ditemukan bahwa faktor erodibilitas tanah di Sub Das Biyonga berjumlah 0,279661 ton/kg.

c. Faktor Panjang dan Kemiringan Lereng (LS)

Untuk menentukan faktor panjang dan kemiringan lereng (LS) daerah penelitian ditentukan dengan melihat secara spasial Peta Kelas Lereng Sub DAS Biyonga pada gambar dibawah ini:

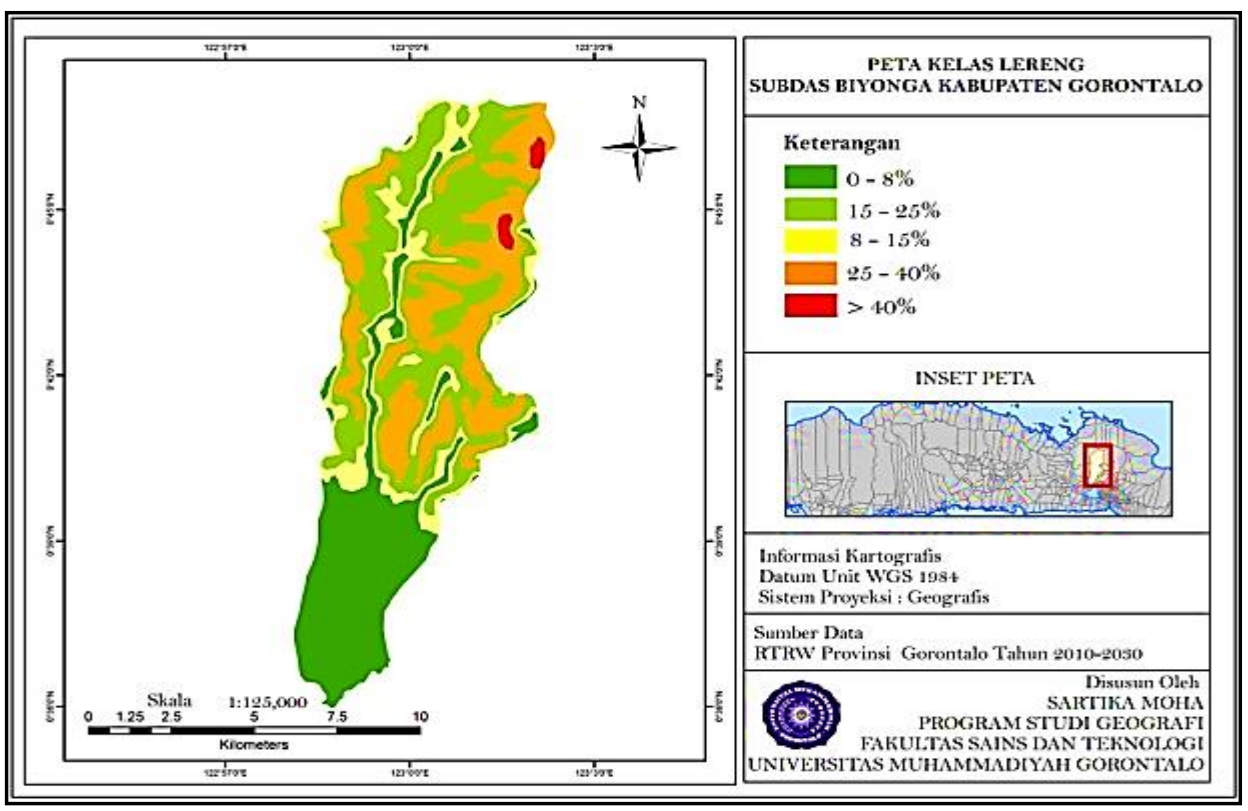

Gambar 1. Peta Kelas Lereng Sub DAS Biyonga

Selain data spasial diatas Kelas Lereng juga dapat disajikan dalam bentuk tabel kelas lereng Sub DAS.Berdasarkan tabel kelas lereng Sub DAS Biyonga memiliki kelas lereng yang berbedabeda beserta luasnya.Pada daerah yang datar memiliki luas sebesar 1618 ha, daerah landai sebesar 197 ha, daerah agak curam sebesar 484 ha, daerah yang curam sebesar 4247 ha dan untuk daerah yang sangat curam sebesar 1712 ha.Sehingga luas lahan terendah berada pada daerah yang landai dengan luas sebesar 197 ha dan daerah yang memiliki luas lahan terbesar berada pada daerah dengan tingkat kelerengan yang curam dengan luas lahan sebesar 1835 ha. Sehingga untuk memperoleh nilai LS Total maka dilakukan cara seperti berikut ini:

$$
\begin{aligned}
& \mathrm{s}=0-8 \%(\text { pada luas lahan } 1618 \mathrm{ha}), \text { maka } \mathrm{LS}=0.40 \\
& \mathrm{~s}=8-15 \%(\text { pada luas lahan } 197 \mathrm{ha}), \text { maka } \mathrm{LS}=1.40 \\
& \mathrm{~s}=15-25 \%(\text { pada luas lahan } 484 \mathrm{ha}), \text { maka } \mathrm{LS}=3.10 \\
& \mathrm{~s}=25-40 \%(\text { pada luas lahan } 4247 \mathrm{ha}), \text { maka } \mathrm{LS}=6.80 \\
& \mathrm{~s}=>40 \% \text { (pada luas lahan } 1835 \mathrm{ha}), \text { maka } \mathrm{LS}=9.50
\end{aligned}
$$
berikut:

Maka didapatkan nilai LS total pada Sub DAS Biyonga dengan perhitungan sebagai

$$
\begin{aligned}
\mathrm{LS} & =(0.40 * 1618)+(1.40 * 197)+(3.10 * 484)+(6.80 * 4247)+(9.50 * 1835) \\
& =(1618+197+484+4247+1835) \\
& =\frac{647,2+27580+1500,4+28879,6+17432,5}{8247} \\
& =\frac{76039,7}{8247} \\
& =9.22
\end{aligned}
$$

\section{d. Faktor Penggunaan Lahan (C)}

Berdasarkan hasil observasi lapangan, penggunaan lahan Sub Das Biyonga di dominasi oleh lahan jagung baik itu lahan yang diperuntukkan untuk pertanian lahan kering, pertanian 
lahan kering campur semak, perkebunan, tanah terbuka, semak belukar, dan hutan sekunder seperti yang disajikan pada data spasial dibawah ini:

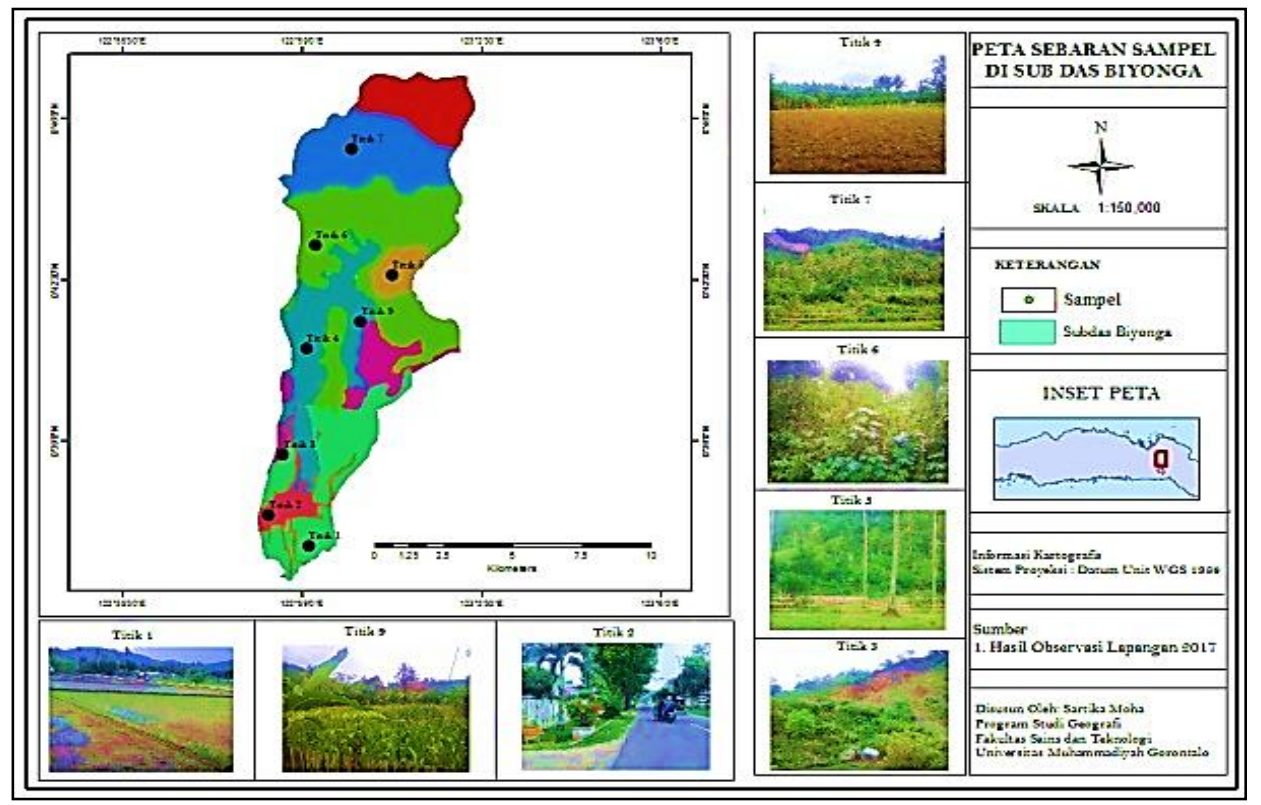

Gambar 2. Titik sampel penggunaan lahan di Sub DAS Biyonga

Pada Gambar 2 dapat dilihat bahwa penggunaan lahan di daerah Sub DAS Biyonga terdapat tujuh titik penggunaan lahan. Dimana pada Titik satu dengan titik koordinat E ( $\left.122^{\circ} 59,1^{\prime} 00^{\prime \prime}\right)$ dan $\mathrm{N}\left(0^{\circ} 36,72^{\prime} 00^{\prime \prime}\right)$ terdapat sawah dua kali padi/tahun, titik dua $\mathrm{E}\left(122^{\circ} 58,33^{\prime} 00^{\prime \prime}\right)$ dan $\mathrm{N}\left(0^{\circ}\right.$ $\left.37,4^{\prime} 00^{\prime \prime}\right)$ terdapat perkampungan, titik tiga $\mathrm{E}\left(122^{\circ} 58,61^{\prime} 00^{\prime \prime}\right)$ dan $\mathrm{N}\left(0^{\circ} 38,7^{\prime} 00^{\prime \prime}\right)$ terdapat tegalan/lading, titik empat E $\left(122^{\circ} 59,06^{\prime} 00^{\prime \prime}\right)$ dan $\mathrm{N}\left(0^{\circ} 41,0^{\prime} 00^{\prime \prime}\right)$ terdapat kebun campur, titik lima $\mathrm{E}\left(122^{\circ} 60^{\prime}, 73^{\prime \prime}\right)$ dan $\mathrm{N}\left(0^{\circ} 42,6^{\prime} 00^{\prime \prime}\right)$ terdapat hutan sejenis, titik enam $\mathrm{E}\left(122^{\circ} 59,24^{\prime} 00^{\prime \prime}\right)$

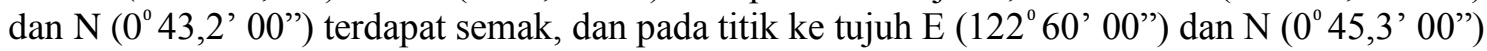
terdapat hutan belukar. Selain gambar titik sampel penggunaan lahan diatas, terdapat juga peta penggunaan lahan di Sub DAS Biyonga seperti pada Gambar 3 berikut:

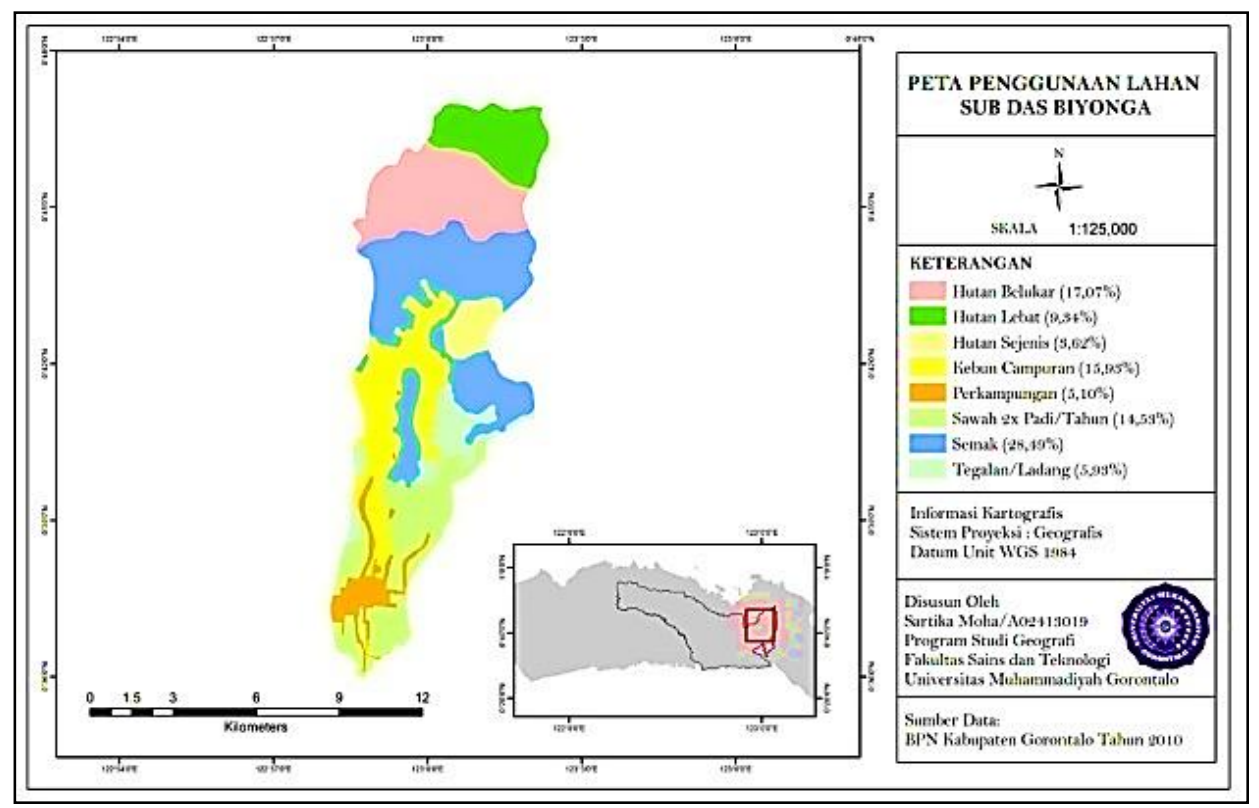

Gambar 3. Penggunaan lahan di Sub DAS Biyonga 
Dan untuk menentukan nilai-nilai dari faktor $\mathrm{C}$ dapat dilihat pada gambar dibawah ini:

Tabel 1. Faktor tanaman C

\begin{tabular}{ccc}
\hline No & Macam Penggunaan & Nilai Faktor \\
\hline 1. & Sawah & 0.01 \\
2. & Tegalan & 0.7 \\
3. & Ubi kayu & 0.8 \\
4. & Jagung & 0.637 \\
5 & Kacang tanah & 0.2 \\
6 & Padi & 0.561 \\
7 & Tebuh & 0.2 \\
8 & Pisang & 0.6 \\
9 & Talas & 0.85 \\
10 & Kebun Campuran & 0.8 \\
11 & Perladangan & 0.4 \\
13 & Hutan produksi & 0.7 \\
14 & Semak belukar/padang rumput & 0.3 \\
\hline
\end{tabular}

Hasil survey (2017) dalam Arsyad (2010)

Berdasarkan tabel faktor tanaman $\mathrm{C}$ dan data spasial diatas, diketahui bahwa nilai faktor tanaman $\mathrm{C}$ bernilai 0.637 , hasil ini berdasarkan survey dan hasil wawancara dengan masyarakat setempat.

e. Faktor Konservasi Tanah (P)

Untuk menentukan nilai dari hasil berbagai aktivitas konservasi pada daerah penelitian dapat dilihat pada tabel dibawah ini:

Tabel 2. Nilai faktor P pada berbagai aktivitas konservasi tanah

\begin{tabular}{clc}
\hline \multicolumn{1}{c}{ Teknik Konservasi Tanah } & Nilai P \\
\hline 1 & Teras Bangku & \\
& a. Sempurna & 0.04 \\
& b. Sedang & 0.15 \\
& c. Jelek & 0.35 \\
2 & Teras Tradisional & 0.40 \\
3 & Padang Rumput (Permanent grass field) & \\
& a. Bagus & 0.04 \\
& b. Jelek & 0.40 \\
\hline
\end{tabular}

Hasil survey (2017) dalam Arsyad (2010)

Tabel diatas berdasarkan hasil pengamatan langsung dilapangan yang mengacu pada hasilhasil penelitian yang telah ada seperti pada tabel 15 , dimana dapat diketahui bahwa di wilayah Sub DAS Biyonga memiliki teknik penanaman dengan menggunakan teras tradisional yang diketahui nilai dari teras tradisional tersebut memiliki nilai P 0.40 .

Selanjutnya setelah parameter-parameter dalam persamaan USLE telah ditentukan nilainya. Selanjutnya nilai A (perkiraan besarnya erosi total) dapat dihitung sesuai dengan persamaan 1: 
a. Besarnya erosi total (A) pada tahun 2012 sampai 2016 yaitu sebagai berikut:

$$
\begin{array}{ll}
\text { A }(2012) & =1305 * 0.279 * 9.22 * 0.637 * 0.40 \\
= & 855.35 \text { ton/thn } \\
\text { A }(2013) & =1147 * 0.279 * 9.22 * 0.637 * 0.40 \\
& =751.79 \text { ton/thn } \\
\text { A }(2014) & =839 * 0.279 * 9.22 * 0.637 * 0.40 \\
& =549.92 \text { ton } / \mathrm{thn} \\
\text { A }(2015) & =527 * 0.279 * 9.22 * 0.637 * 0.40 \\
\text { A }(2016) & =345.42 \text { ton } / \text { thn } \\
& =1205 * 0.279 * 9.22 * 0.637 * 0.40 \\
& =789.81 \text { ton } / \text { thn }
\end{array}
$$

Besarnya nilai erosi selama 5 tahun dari tahun 2012 hingga 2016 memiliki nilai relatif berbeda. Adapun besarnya nilai erosi disajikan pada Gambar 4 berikut:

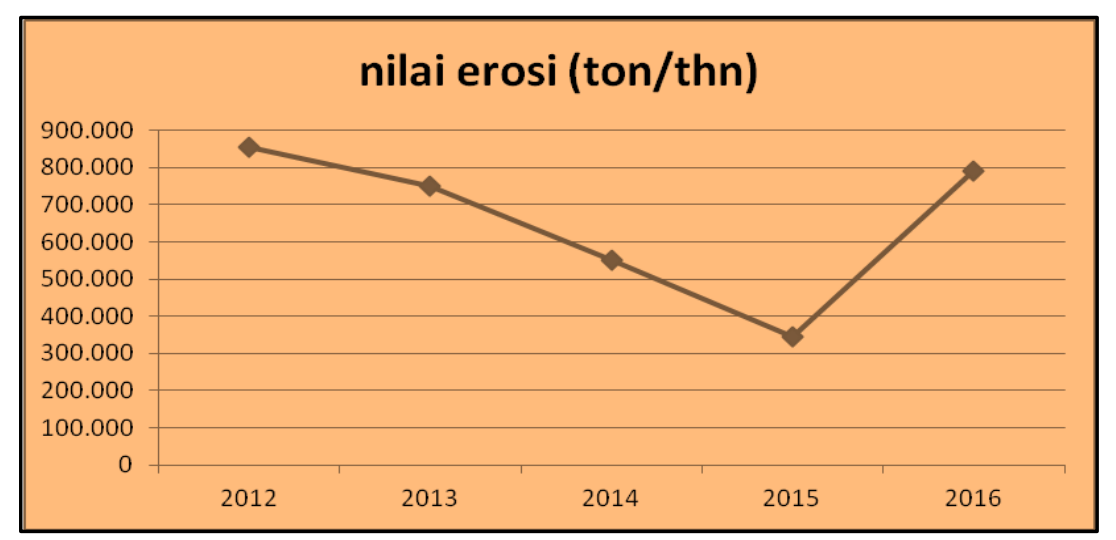

Gambar 4. Nilai erosi Sub DAS Biyonga Tahun 2012-2016

Gambar 4 menunjukan bahwa nilai erosi terbesar di daerah Sub DAS Biyonga pada tahun 2012 dengan jumlah erosi yaitu 855.35 ton/thn hal ini diakibatkan karena pada tahun 2012 jumlah curah hujan didaerah tersebut meningkat sebesar 1305 mm sedangkan pada tahun 2015 jumlah erosi menurun menjadi 345.42 ton/thn hal ini diakibatkan karena pada tahun 2015 jumlah curah hujannya menurun menjadi $527 \mathrm{~mm}$ serta pada tahun tersebut telah terjadi musim kemarau yang berkepanjangan sehingga mengakibatkan erosinya pun menurun. Dari total keseluruhan pada daerah Sub DAS Biyonga didapatkan nilai erosi totalnya selama 5 tahun yaitu:

$$
\begin{aligned}
\mathrm{A} & =3.292 .286 * 8915: 5 \\
& =5.870 .145,93 \mathrm{ton} / \mathrm{ha} / \mathrm{thn}
\end{aligned}
$$

Dari hasil perkalian USLE di atas, maka didapatkan jumlah erosi total (A) di Sub DAS Biyonga adalah 5.870.145,93 (ton/ha/thn).

\section{Pendugaan Laju Sedimentasi}

\section{a.Penetapan SDR}

Penetapan SDR (Sediment Delivery Ratio) dalam Arsyad (2010) yaitu 0.41 A - ${ }^{0.3}$. 
Dimana:

SDR = Rasio pelepasan Sedimen

A $\quad=$ Luas DAS $(\mathrm{km} 2)$.

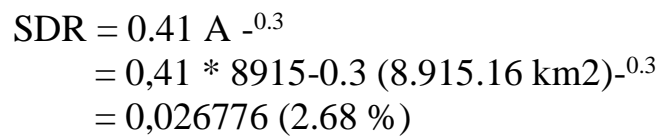

b. Hasil sedimen

Untuk mendapatkan besaran hasil sedimentasi di Sub DAS Biyonga selama 5 (lima) tahun sesuai perhitungan dengan persamaan 2 , sehingga didapatkan:

$\mathrm{Y}=\mathrm{E}(\mathrm{SDR}) \mathrm{A}$

$\mathrm{Y}=5.870 .145,93(2.68) 8915$

$=1.402 .507,01($ ton/ha/thn $)$

Nilai total sedimentasi yang ada di Sub DAS Biyonga selama 5 tahun yaitu 1.402.507,01 (ton/ha/thn). Dari hasil prediksi tersebut dapat diketahui bahwa besarnya laju sedimentasi pada Sub DAS Biyonga selama kurun waktu tersebut sebesar 1.402.507,01 (ton/ha/thn).

\section{Pembahasan}

\section{Laju Erosi}

a. Faktor Erosivitas Hujan

Data curah hujan yang digunakan untuk menghitung faktor erosivitas diperoleh dari data curah hujan bandar udara djlaludin gorontalo. Sebaran data curah hujan yang diambil dari suatu stasiun memiliki sebaran sampai $10 \mathrm{~km}$. Curah hujan rata-rata bulanan untuk Sub DAS Biyonga berkisar antara $107 \mathrm{~mm}$ sampai dengan $403 \mathrm{~mm}$, dengan curah hujan tertinngi terjadi pada bulan Mei dan terendah pada Bulan September. Curah hujan mempunyai peranan yang cukup tinggi terhadap erosi tanah yang terjadi.Pada daerah yang berlereng terjal, erosivitas hujan yang sangat tinggi sangat berpengaruh terhadap besarnya erosi.

Data curah hujan terdiri dari jumlah curah hujan bulanan selama 5 tahun yaitu dari tahun 2012 sampai tahun 2016. Sehingga setelah dilakukan perhitungan diperoleh nilai erosivitas seperti yang ditunjukan pada tabel 12. Dari hasil perhitungan menunjukan bahwa faktor erosivitas hujan berdasarkan persamaan lenvain yaitu pada tahun 2012 bernilai $1305 \mathrm{~mm} / \mathrm{tahun}, 2013$ bernilai $1147 \mathrm{~mm} /$ tahun, 2014 bernilai $839 \mathrm{~mm} /$ tahun, 2015 bernilai $527 \mathrm{~mm} /$ tahun dan pada tahun 2016 bernilai $1205 \mathrm{~mm} /$ tahun. Sehingga dari faktor erosivitas hujan selama 5 tahun diketahui bahwa nilai $\mathrm{R}$ terbesar yaitu pada tahun 2012 sedangkan niali $\mathrm{R}$ terendah yaitu pada tahun 2015.

\section{b. Faktor Erodibilitas Tanah}

Erodibilitas tanah $(\mathrm{K})$ menunjukan mudah tidaknya tanah untuk tererosi. Pendugaan nilai $\mathrm{K}$ pada daerah penelitian ini menggunakan parameter sifat-sifat tanah menurut cara yang ditentukan Wischmeier (1971) dalam Arsyad (2010). Nilai perhitungan faktor erodibilitas tanah dapat dilihat pada halaman 28.Dari hasil perhitungan tersebut didapatkan nilai dari erodibilitas tanah sebesar 0,279661 ton $/ \mathrm{kg}$, sehingga semakin tinggi nilai dari $\mathrm{K}$ berarti tanah tersebut semakin mudah tererosi.Dari hasil perhitungan tersebut bahwa nilai dari erodibilitas tanah dapat dipengaruhi oleh tekstur, struktur, permeabilitas dan kandungan bahan organik tanah.

1). Tekstur tanah

Tekstur tanah merupakan perbandingan relatif dari partikel tanah, seperti pasir, debu, dan lempung dalam suatu massa tanah. Tekstur tanah akan sangat menentukan sifat-sifat tanah yang lain, seperti kecepatan infiltrasi dan kemampuan pengikatan air oleh tanah yang dapat menentukan terjadi tidaknyaaliran permukaan. Tekstur tanah juga berpengaruh pada erodibilitas tanah yaitu dengan semakin kasarnya tekstur tanah, maka nilai $\mathrm{K}$ akan cenderung semakin besar yang berarti bahwa semakin tinggi nilai $\mathrm{K}$ maka tanah tersebut akan semakin peka atau mudah tererosi. Sebaliknya semakin halus tekstur suatu tanah, nilai K akan semakin rendah yang berarti tanah tersebut resisten terhadap erosi.

Tanah bertekstur kasar mempunyai kapasitas infiltrasi yang tinggi, sedangkan tanah yang 
bertekstur halus mempunyai kapasitas infiltrasi kecil, sehingga dengan curah hujan yang cukup rendah pun akan menimbulkan limpasan permukaan. Tanah pasir mempunyai kapasitas infiltrasi yang tinggi, pasir dengan ukuran yang lebih besar akan lebih sukar terhanyutkan, tetapi kemantapan strukturnya rendah dikarenakan antara partikel yang satu dengan lainnya tidak memiliki daya ikat yang besar. Sedangkan tanah yang banyak mengandung banyak debu memiliki erodibilitas yang tinggi, sehingga paling mudah tererosi, debu sangat mudah dihanyutkan oleh air, debu mudah jenuh air sehingga kapasitas infiltrasinya cepat menurun. Sedangkan kemantapan strukturnya sangat rendah karena daya kohesi antara partikelnya sangat lemah.Debu dan pasir sulit membentuk struktur yang mantap dan oleh karenanya tanah yang mengandung debu dan pasir tinggi lebih pekaterhadap erosi.

2). Bahan Organik Tanah

Banyaknya bahan organik yang terdapat di dalam tanah akan menentukan tingkat kesuburan serta kondisi fisik maupun kimiawi tanah. Bahan organik tanah itu sendiri dapat mempengaruhi nilai $\mathrm{K}$ karena terkait dengan fungsi bahan organik sebagai bahan perekat tanah dalam pembentukan agregat tanah.Kandungan bahan organic pada daerah penelitian tergolong sedang.Hal ini dapat disebabkan oleh adanya erosi yang mempunyai kemampuan menngerus bahan organik yang sebagian besar berada di tubuh tanah bagian atas.

3). Struktur tanah

Struktur pada daerah penelitian semua tergolong gumpal bersudut.Hal ini menunjukan bahwa di daerah penelitian tersebut telah terjadi erosi karena sangat sedikit ditemukan adanya agregat dan bahkan banyak ditemukan tanah-tanah bertekstur pasir.Hal itu didukung oleh sedikitnya kandungan lempung dan bahan organic yang mampu berperan sebagai bahan perekat. Tanah-tanah bertekstur kasar membentuk strutur tanah yang ringan, sebaliknya tanah-tanah yang berbentuk atau tersusun dari tekstur halus menyebabkan terbentuknya tanah-tanah yang berstruktur berat.

4). Permeabilitas

Permeabilitas sangat tergantung pada ukuran butir tanah (tekstur), bentuk dan diameter pori-pori tanah sera tebal selaput lengas/hidratasi zarah. Semakin halus tekstur tanah maka permeabilitasnya akan semakin lambat. Namun apabila semakin kasar tekstur tanah maka permeabilitasnya semakin cepat.

\section{c. Faktor Panjang dan Kemiringan Lereng (LS)}

Unsur topografi yang berpengaruh terhadap erosi adalah panjang lereng dan kemiringan lereng.Pada daerah penelitian tersebut memiliki topografi dari yang datar sampai yang amat sangat curam.Dari peta kelas lereng Sub DAS Biyonga dapat diketahui bahwa Sub DAS Biyonga terletak pada kemiringan lereng yang beragam dari yang datar hingga bergunung.

Bersarkan bentuk topografinya, areal Sub DAS Biyonga dikelompokan menjadi 5 kelas kemiringan yaitu $0-8 \%, 8-15 \%, 15-25 \%, 25-40 \%$ hingga $>40 \%$. Serta memiliki luas lahan yang beragam pula seperti pada tingkat kelerengan yang datar memiliki luas sebesar 1.618 ha, daerah landai memiliki luas 197 ha, daerah agak curam memiliki luas 484 ha, daerah curam memiliki luas 4.624 ha, dan daerah yang sangat curam sebesar 1.712 ha.

Sehingga untuk menghitung Faktor LS digunakan perhitungan dengan persamaan Wicshmeier dengan nilai panjang dan kemiringan lereng tersebut sebesar 9.22

d. Faktor Penggunaan Lahan (C) dan Konservasi tanaman (P)

Faktor pengelolaan tanaman dan konservasi tanaman dapat diketahui dari peta penggunaan lahan atau penutupan lahan serta pengamatan langsung di lapangan.Pada penelitian ini faktor $\mathrm{C}$ dan $\mathrm{P}$ diketahui dengan melakukan pengamatan langsung serta wawancara di lokasi penelitian.Hal ini dilakukan agar nilai CP yang didapat benar-benar aktual atau kondisi terkini di lokasi, sehingga diharapkan nilai hasil pendugaan erosi memiliki tingkat keakuratan yang tinggi. Setelah melakukan pengamatan dan wawancara di lapangan, maka diperoleh pula hasil bahwa faktor $\mathrm{C}$ memiliki nilai 0.637 dimana pada daerah penelitian tersebut didominasi oleh lahan jagung baik untuk lahan peruntukan lahan kering, pertanian lahan kering campur semak, perkebunan, tanah terbuka, semak belukar maupun hutan sekunder.

Dari hasil pengolahan data spasial peta penggunaan lahan di Sub DAS Biyonga didaptakan sekian persen di setiap penggunaan lahan yang ada. Dimana hutan belukar memiliki persentase sebesar $17.07 \%$, hutan lebat $9.34 \%$, hutan sejenis $3.62 \%$, kebun campuran $15.93 \%$, perkampungan $5.10 \%$, sawah $14.53 \%$, semak $28.49 \%$ dan tegalan/lading memili persentase 
sebesar 5.93\%. Untuk tindakan konservasi yang sudah dilakukan pada daerah penelitian adalah dengan menggunakan teras bangku dengan konstruksi sedang.Selain itu juga ditanami beberapa tanaman tahunan dengan sengaja sebagai salah satu upaya konservatif seperti kelapa.Pada darah penelitian juga terdapat banyak perkebunan terutama jagung dan tanaman kebun lainnya seperti pisang dan singkong namum dengan jumlah hanya sedikit.Berdasarkan pengamatan langsung dilapangan bahwa Konservasi tanah di wilayah penelitian kebanyakan menggunakan teknik konservasi teras bangku Sehingga untuk nilai konservasi tanah pada Sub DAS Biyonga memiliki nilai 0.40 .

\section{Laju Sedimentasi}

Hasil prediksi erosi di Sub DAS Biyonga diketahui bahwa nilai erosi dengan menggunakan persamaan USLE hasilnya bervariasi, dari tahun 2012 nilai erosinya berjumlah 855.35 ton/thn, (2013) 751.79 ton/thn, (2014) 549.92 ton/thn, (2015) 345.42 ton/thn dan pada tahun (2016) 789.81 ton/thn. Sehingga dari hasil perhitungan tersebut diketahui nilai erosi tertinggi yaitu pada tahun 2012 dengan erosi 855.35 ton/thn dan nilai erosi terendah yaitu pada tahun 2015345.42 ton/thn dengan data curah hujan yang bervariasi. Selanjutnya untuk pendugaan laju sedimentasi atau nilai total dari Sedimentasi di Sub DAS Biyonga berdasarkan prediksi SDR dan Nilai Erosi total hasilnya yaitu sebesar 1.402.507,01 ton/ha/thn.

Sehingga diprediksikan Sub Das Biyonga menyumbang sedimentasi terlalu banyak selama 5 tahun ini ke danau limboto Hasil prediksi sedimentasi tersebut disebabkan adanya jumlah curah hujan yang berbeda-beda pada setiap tahun, kemiringan lahan, kekasaran permukaan tanah, jarak sumber erosi ke sungai, bentuk lereng dan penutupan permukaan tanah.

\section{KESIMPULAN}

Berdasarkan hasil penelitian terhadap pendugaan laju sedimentasi yang di lakukan di Sub DAS Biyonga, maka diperoleh kesimpulan sebagai berikut:

1. Laju erosi rata-rata yang terjadi di Sub DAS Biyonga di hitung dengan metode USLE yang dihitung berdasarkan perbedaan faktor lereng (LS) dan faktor vegetasi, erosivitas hujan, erodibilitas tanah, serta faktor konservasi (CP). Sehingga laju erosi sub das biyonga untuk 5 tahun yaitu sebesar 5,870,145.93 ton/ha/thn. Untuk mencegah terjadinya erosi maka perlu dilakukan reboisasi di sekitar Sub DAS Biyonga dan pembuatan bangunan penangkal erosi.

2. Berdasarkan hasil perhitungan sedimen persatuan luas diketahui bahwa nilai sedimentasi terbesar selama 5 tahun yaitu sebesar $1.402 .507,01 \mathrm{ton} / \mathrm{ha} / \mathrm{thn}$. Artinya dari hasil tersebut Sub DAS Biyonga memerlukan penanganan yang lebih serius lagi terhadap proses erosi.

\section{DAFTAR PUSTAKA}

Arsyad, S. (2010). Konservasi tanah dan air. Penerbit IPB Press. Bogor

Asdak, C. (2014). Hidrologi dan Pengelolaan Daerah Aliran Sungai. Gadjah Mada University Press. Yogyakarta.

Assyakur. (2008). Prediksi Erosi dengan Menggunakan Metode Usle dan SIG Berbasis Pixel di daerah Tangkapan AIR Danau Buyan, Universitas Udayana.Bali.

Asir, L. (2012). Hidrologi dan Pengelolaan Daerah Aliran Sungai.Gadjah Mada University Press.Yogyakarta.

Balai Pengelolaan Daerah Aliran Sungai Bone-Bolango. (2010). Penyusunan Pengelolaan DAS Limboto Terpadu.Gorontalo.

Hardjowiwego, S. (2007). Ilmu Tanah. Akademika Pressindo. Jakarta.

Husnan, R. (2007). Intensitas Bed Load Sungai Biyonga. Jurnal Teknik.UNG.

Ilahude dan Nurdin. (2013). Penggunaan Lahan Kering di DAS Limboto Provinsi Gorontalo Untuk Pertanian Berkelanjutan.UNG.

Jauhari, I. M. (2012). Prediksi Erosi di Sub-Sub DAS Lengkese, Sub DAS Lengkese, Hulu DAS Jeneberang.Skripsi. Universitas Hasanudin. Makassar.

Kementrian Kehutanan. (2013). Pedoman Identifikasi Kerakteristik Daerah Aliran Sungai. Jakarta: Kementrian Kehutanan.

Kusmawati. (2012). Prediksi Erosidan Perencanaan Konservasi Tanah dan Air Pada Daerah Aliran Sungai Saba. 
Legowo WD. (2013). Pendugaan Erosi dan Sedimentasi dengan Menggunakan Model GeoWEPP (Studi Kasus DAS Limboto,Provinsi Gorontalo). Jurnal ITB,Bandung, Institut Teknologi Bandung.

Lihawa, F. (2011). Bahan Ajar Konservasi dan Reklamasi Lahan. Program Studi Geografi, Fakultas MIPA Universitas Negeri Gorontalo Press: Gorontalo.

Lubis. (2015). Pendugaan Erosi Aktual Berdasarkan Metode Usle Melalui Pendekatan Vegetasi, Kemiringan Lereng dan Erodibilitas di Hulu Sub DAS Padang, Universitas Pertanian USU. Medan.

Mawardi, M. (2012). Rekayasa Konservasi Tanah dan Air. Bursa Ilmu: Yogyakarta

Neitsch. (2011). Soil and Water Assessmen Tool Theoretical Documentation. Agriculture Research Service and Texas Agricultur Experiment Station.Texax.

Purnama. (2008). Pendugaan Erosi dengan Metode Usle di Situ Bojongsari, Depok. Fakultas Teknologi Pertanian. Intitut Pertanian Bogor.

Qurratul. (2008). Prediksi Tingkat Bahaya Erosi Dengan Menggunakan Metode Usle Dilereng Timur Gunung Sindoro. Skripsi. Universitas Sebelas Maret. Surakarta.

Supangat, A.B. (2014). Perhitungan Sedimentasi.Buku. Balai Penelitian Teknologi Kehutanan Pengelolaan DAS. Surakarta.

Suripin, (2012). Pelestarian Sumber daya tanah dan air.Andi.Universitas Michigan.

Troeh et al. (2008). Soil and Water Conservation; for productivity and environmental protection 4th edition.New Jersey.Pearson Prentice Hall.

Yuan. (2016). Soil Erosion Asessment Of The Poyang Lake Basin,China:Using USLE, GIS and Remote Sensing. 